Małgorzata WALENDZIK ${ }^{1}$, Tomasz KAMIŃSKI ${ }^{1}$, Piotr PAWLAK ${ }^{1}$, Konstantinos DEMESTICHAS ${ }^{2}$

${ }^{1}$ Motor Transport Institute (Instytut Transportu Samochodowego)

${ }^{2}$ National Technical University of Athens

\title{
THE ANALYSIS OF ORGANIZATIONAL AND LEGAL POSSIBILITIES TO REDUCE THE DANGERS RELATED TO ROAD TRANSPORT OF DANGEROUS GOODS IN POLAND
}

\author{
Analiza organizacyjnych i prawnych możliwości \\ ograniczenia zagrożeń związanych z przewozem towarów \\ niebezpiecznych w Polsce
}

\begin{abstract}
According to the data of the Supreme Audit Office, every day in Poland, 20 thousand of vehicles transport dangerous goods by road. Annually 150 million tons of dangerous goods are transported, including flammable, explosive, corrosive, toxic and radioactive materials. The article presents an analysis of aggregated data obtained from particular institutions, participating in different way in monitoring and controlling transport of this type of goods. The analysis of combined data has enabled the identification of organizational and legal possibilities for reducing the dangers associated with the road transport of dangerous goods in Poland.
\end{abstract}

Keywords: ADR, road safety, transport of dangerous goods

Streszczenie: Wedtug danych NIK po polskich drogach codziennie porusza się 20 tys. pojazdów, które przewoża towary niebezpieczne, a rocznie przewożonych jest $150 \mathrm{mln}$ ton towarów niebezpiecznych, do których należa materiały łatwopalne, wybuchowe, żrace, trujace i promieniotwórcze. $W$ artykule przedstawiono analizę zagregowanych danych Państwowej Straży Pożarnej, dotyczacych udziału $w$ likwidacji zdarzeń z udziatem materiałów niebezpiecznych. Analiza przepisów prawa i danych w tym zakresie umożliwiła określenie organizacyjnych i prawnych możliwości ograniczania zagrożeń zwiazanych $z$ drogowym przewozem towarów niebezpiecznych w Polsce.

Słowa kluczowe: ADR, BRD, przewóz towarów niebezpiecznych 


\section{Introduction}

Transport is an important element of every country's economy. Effective transport significantly contributes to the general socio-economic development of the state, enables the efficient functioning of individual sectors of the national economy and is a prerequisite for maintaining the well-being of each country. The relationships between transport and other sectors of the economy are mutual. The vast majority of transport on land in the EU is the road transport and this is a constant increasing trend. Road transport, which is the most-used form of transport, also has the largest share in environmental pollution, and thus has become one of the greatest civilization threats. Air pollution, noise emissions, traffic accidents, traffic congestion, water pollution, an increasing land consumption are associated with high costs that all inhabitants of the Earth must suffer, not just transport users. Air pollution is the cause of chronic and serious illnesses such as asthma, cardiovascular disease and lung cancer. Air pollution is still the main environmental cause of premature death in the EU, leading to over 400,000 premature deaths per year, as estimated.

The effects of road accidents and breakdowns involving vehicles intended for the transport of dangerous goods, are threat to the health and life of people in the zone of the incident, and this accidents may affect the degradation of the natural environment [1]. In accordance with art. 5 of the Polish Constitution, ensuring the security of citizens and ensuring environmental protection is one of the main tasks of the Republic of Poland. According to the data of the Supreme Audit Office, every day in Poland, 20 thousand of vehicles transport dangerous goods by road. Annually 150 million tons of dangerous goods are transported, including flammable, explosive, corrosive, toxic and radioactive materials.

Transport of dangerous goods and materials is about $50 \%$ of all transported goods. All means of transport: roads, rail, air, sea and inland waterway are used for their transportation. However, most often, the transport of dangerous goods is carried out on land, i.e. road and rail. Economic development, improvement of road infrastructure and an increase in the number of transport companies have caused that the amount of dangerous goods transported by road has increased rapidly in recent years. Main reasons for taking special care in the transport of dangerous goods by road are the safety of drivers and passengers and the reduction of the environmental pollution threat. Transport of dangerous goods such as flammable, corrosive or poisonous materials is associated with an increased danger, therefore it is extremely important to control the entire transport process, at every stage of its implementation and to properly plan the routes, which could increase safety $[2,8]$. The process of transporting dangerous goods should be carried out efficiently and without disturbances, it is necessary to comply with legal regulations in this respect and solutions facilitating safe reach to the destination. In order to exclude or minimize the dangers related to the transport of dangerous goods, individual, both national and international agreements and laws refer to every type of transport. 


\section{International and national legal regulations}

Dangerous goods pose a threat to people, property and the natural environment. This substances may have solid form (powdery, granular materials, in the form of pastes and gels), liquid and gaseous forms. This can also be items that contain such dangerous materials that, according to the provisions of ADR, RID or ADN (road, rail or inland waterway transport, respectively) are allowed for transport under the conditions specified in ADR regulation. Of course, there are also dangerous goods that are excluded from ADR regulation. In terms of $\mathrm{ADR}$, dangerous goods could be substances, preparations with flammable, explosive, corrosive, toxic, oxidizing, radioactive or environmentally hazardous. They can be strictly defined groups of dangerous goods, e.g. paints, fireworks, grenades or batteries. However, dangerous goods may be also groups of goods with similar specified characteristics as e.g. alcohols or combustible, liquid and poisonous material.

International and national law consists of a wide spectrum of legal regulations that specify the method of providing services in the field of transport of dangerous goods. The law regulations in relation to specific types of goods transported by road contains detailed legal requirements which must be strictly observed. The basic regulations that specify the transport of dangerous goods are included in documents such as [3, 4]:

- The European Agreement Concerning the International Carriage of Dangerous Goods by Road. This agreement regulates the issue of road transport of dangerous goods in the EU and throughout Europe. Agreement was drawn up in Geneva on September 30, 1957. Many EU directives and legal acts of individual member states, including Polish provisions, was issued having regard to this agreement. The ADR agreement is the basic legal act regulating the carriage of dangerous goods by road in European countries. Regulations of this agreement are amended in a two-year cycle, which allows it to be adapted to the current conditions. The updated official Polish language version of these agreement (consolidated text) is announced in the Journal of Laws of The Republic of Poland. The agreement, apart from specifying 9 hazard classes, in addition to specifying special storage conditions and transport methods, additionally imposes on drivers obligation to complete a basic training and pass a special exam. This exam checks the driver's level of knowledge regarding the regulations about domestic and international transport of dangerous goods. The course should be renewed once every 5 years, and additional specialized training must be performed by tanker drivers and drivers which transport explosives,

- Directive 2008/68/EC of the European Parliament and of the Council of 24 September 2008 on the inland transport of dangerous goods,

- Council Directive 95/50/EC of 6 October 1995 on uniform procedures for checks on the transport of dangerous goods by road,

- Act of 19 August 2011 on the transport of dangerous goods - consolidated (Dz. U. 2020 item. 154),

- Act of 20 June 1997 on the traffic regulations (Dz. U. 2020, item. 110), 
- Regulation of the Minister of Transport, Construction and Maritime Economy of 14 August 2012 on the form for the annual activity report on the transport of dangerous goods and how to fill it in (Dz. U. 2012 item. 966),

- Regulation of the Minister of Transport, Construction and Maritime Economy of 29 May 2012 on the conducting courses on the scope of dangerous goods transport (Dz. U. 2019, item. 555),

- Regulation of the Minister of Infrastructure and Development of 7 May 2015 on the obtaining the certificate of an advisor for the safety of dangerous goods transport (Dz. U. 2015 item. 718),

- Regulation of the Minister of Transport, Construction and Maritime Economy of 15 February 2012 on the ADR vehicle approval certificate (Dz. U 2017, item. 695),

- Regulation of the Minister of Transport, Construction and Maritime Economy of 25 April 2012 on the report concerning control of the transport of dangerous goods by road (Dz. U. 2012 item. 483),

- Regulation of the Minister of Transport, Construction and Maritime Economy of 13 April 2012 on transportable pressure equipment (Dz. U. 2012 item. 436).

National regulations may not infringe article 2 of the ADR Agreement, which provides that the transport of dangerous goods may be realized if the requirements about their packaging, marking, classification, documentation also construction, equipment and operation of the vehicle used for the transport of dangerous goods are met. Therefore it should be assumed that acts of international law are of decisive importance for the creation of Polish law.

In addition to knowledge of national and EU regulations in the field of road transport of dangerous goods, companies transporting dangerous goods through several countries should also check whether additional transit requirements have been introduced in these countries. Among them are:

- requirements concerning transport of dangerous goods, in case of an extreme weather conditions, natural disasters, in state of emergency or during the war,

- crossing bridges, tunnels and other similar facilities,

- access to ports and other terminals,

- use of combined transport, e.g. trains or ferries,

- periodic vehicle traffic exclusion,

- $\quad$ routes through areas, such as of high ecological sensitivity, densely populated or containing dangerous industrial installations.

Countries that apply additional requirements on their territory are obliged to notify them to the Secretariat of the United Nations Economic Commission for Europe. Secretariat is obliged to notify those requirements to the Member States participating in the ADR Agreement. Road transport of dangerous goods is primarily associated with the ADR Agreement, which is an administrative and legal act, and is a commonly used standard. Meanwhile, the CMR Convention is equally important. It sets out the principles of liability of the entieties from the contract of carriage for violation of the conditions during transport of dangerous goods. The ADR agreement specify primarily obligations to public authorities, and the provisions of the CMR Convention relate only to mutual rights and obligations of 
the parties. Carriers, senders and recipients should cooperate with each other and with the competent authorities in the area of exchanging information on dangers, security measures and dealing with security incidents.

An important issue is also the transport of high-risk dangerous goods, which may be used, contrary to their purpose, in terrorist attacks and thus cause serious consequences such as numerous victims, mass destruction, or socio-economic disorganization, especially in the case of class 7 goods (radioactive materials).

In the case of transport of high-risk dangerous goods or radioactive materials, all participants of the transport process should adopt, implement and apply a security plan. These precautions are taken to minimize the danger of theft or the use of dangerous goods contrary to their intended use. During transport, devices and security measures should be used to effectively prevent the theft of these vehicles and their cargo. The application of the above-mentioned measures should in no way impede the conduct of rescue and fire-fighting operations.

The transport of dangerous goods is carried out in properly secured parcels and tanks, due to the fact that these goods may be in solid form (loose or granulated materials, materials in the form of pastes and gels) and in liquid or gas form. These include, among others: gasoline, some solvents, paints, some fertilizers, acids, gases (e.g. propane or acetylene). Certain liquids and gases are dangeorus, which due to their form can only be transported in packages or tanks, as well as subjects containing dangerous components, e.g. lighters, batteries, ammunition, fireworks, etc. Radioactive waste are subject to special transport conditions. Each type of road transport of dangerous goods is described in the ADR Agreement and each transport can be carried out only after meeting all requirements and under the conditions specified in the regulations.

Participants obligations of transport of dangerous goods by road are specified in the ADR Agreement and in the Act on the transport of dangerous goods. In accordance with applicable regulations, all participants in the transport process of dangerous goods, i.e. road transport operators, shippers, warehousemen and all other persons involved in transport operations, should be aware of the threat posed by dangerous goods. According to their obligations, they should comply with the regulations on securing the transport of dangerous goods. The carriage of dangerous goods by road should be subject to special control and supervision of designated public administration bodies and rescue services. As a result of the lack of proper supervision over the carriage of dangerous goods by road, accidents may occur. This transport is often carried out through densely populated places, near schools, large housing estates or shopping centers. Breakdowns, collisions and accidents that may occur during the transport of dangerous goods can cause an explosion, fire, radiation as well as other dangers associated with the transport of toxic materials, which pose a great danger to road users, inhabitants and natural environment. Table 1 includes the list of high-risk dangerous goods. 
Table 1

List of high risk dangerous goods

\begin{tabular}{|c|c|c|c|c|c|}
\hline \multirow[b]{2}{*}{ Class } & \multirow[b]{2}{*}{ Subclass } & \multirow[b]{2}{*}{ Material or item } & \multicolumn{3}{|c|}{ Quantity } \\
\hline & & & $\begin{array}{l}\text { Tank } \\
(l)^{\mathrm{e}}\end{array}$ & $\begin{array}{l}\text { Carriage } \\
\text { in bulk } \\
(\mathrm{kg})^{\mathrm{d}}\end{array}$ & $\begin{array}{l}\text { Number } \\
\text { of } \\
\text { parcels } \\
(\mathrm{kg})\end{array}$ \\
\hline \multirow{5}{*}{1} & 1.1 & $\begin{array}{l}\text { Explosives and objects with } \\
\text { explosives }\end{array}$ & a & a & 0 \\
\hline & 1.2 & $\begin{array}{l}\text { Explosives and objects with } \\
\text { explosives }\end{array}$ & a & a & 0 \\
\hline & 1.3 & $\begin{array}{l}\text { Explosives and objects with } \\
\text { explosives of compatibility group C }\end{array}$ & $\mathrm{a}$ & a & 0 \\
\hline & 1.4 & $\begin{array}{l}\text { Explosives and objects with } \\
\text { explosives UN: } 0104,0237,0255 \text {, } \\
0267,0289,0361,0365,0366,0440 \text {, } \\
0441,0455,0456 \text { and } 0500\end{array}$ & $\mathrm{a}$ & a & 0 \\
\hline & 1.5 & $\begin{array}{l}\text { Explosives and objects with } \\
\text { explosives }\end{array}$ & 0 & a & 0 \\
\hline \multirow{2}{*}{2} & \multirow{2}{*}{-} & $\begin{array}{l}\text { Non-toxic flammable gases } \\
\text { (classification codes containing only } \\
\text { the letters F or FC) }\end{array}$ & 3000 & $\mathrm{a}$ & $\mathrm{b}$ \\
\hline & & $\begin{array}{l}\text { Toxic gases (classification codes } \\
\text { containing the letters T, TF, TC, TO, } \\
\text { TFC or TOC) excluding aerosols }\end{array}$ & 0 & $\mathrm{a}$ & 0 \\
\hline \multirow[t]{2}{*}{3} & \multirow[t]{2}{*}{-} & $\begin{array}{l}\text { Flammable liquids, packing groups I } \\
\text { and II }\end{array}$ & 3000 & a & $\mathrm{b}$ \\
\hline & & Desensitized iquid explosives & 0 & $\mathrm{a}$ & 0 \\
\hline 4.1 & - & Desensitized solid explosives & $\mathrm{a}$ & $\mathrm{b}$ & 0 \\
\hline 4.2 & - & Materials of packing group I & 3000 & $\mathrm{a}$ & $\mathrm{b}$ \\
\hline 4.3 & - & Materials of packing group I & 3000 & $\mathrm{a}$ & $\mathrm{b}$ \\
\hline \multirow[b]{2}{*}{5.1} & & Oxidizing liquids, packing group I & 3000 & $\mathrm{a}$ & $\mathrm{b}$ \\
\hline & - & $\begin{array}{l}\text { Perchlorates, ammonium nitrate, } \\
\text { ammonium nitrate fertilizers and } \\
\text { ammonium nitrate in emulsions, } \\
\text { suspensions or gels }\end{array}$ & 3000 & 3000 & $\mathrm{~b}$ \\
\hline 6.1 & - & Toxic substances of packing group I & 0 & $\mathrm{a}$ & 0 \\
\hline 6.2 & - & $\begin{array}{l}\text { Infectious substances of category A } \\
\text { (UN } 2814 \text { and 2900, except for } \\
\text { animal material) }\end{array}$ & a & 0 & 0 \\
\hline 8 & - & $\begin{array}{l}\text { Corrosive substances in packing } \\
\text { group I }\end{array}$ & & & \\
\hline
\end{tabular}


${ }^{\mathrm{a}}$ not applicable; ${ }^{\mathrm{b}}$ regardless of the quantity of goods, the provisions of the chapter 1.10.3 ADR agreement do not apply; ${ }^{c}$ value in this column applies only if carriage in a tank is authorized, in accordance with Chapter 3.2 of the ADR agreement table A column (10) or (12). For materials that are not approved for carriage in tanks, the instructions in this column do not apply; ${ }^{d}$ value in the column applies only if the carriage in bulk is allowed in accordance with Chapter 3.2 of the ADR agreement table A column (10) or (17). For materials that are not approved for carriage in bulk, the instructions in this column do not apply.

Source: ADR agreement, 2019, chapter 1.10.

\section{Supervision and control of dangerous goods transported by road}

Basis for the safe transport of dangerous goods is proper packing of this type of materials, correct loading, unloading in accordance with the regulations, and implementation of the right transport route in compliance with ADR regulations [9].

The supervision over the transport of dangerous goods and over the units related to this transport in the field of road and rail transport of dangerous goods is executed by the Minister competent for transport, through units directly subordinate to him. In particular, this Minister verifies the correctness of actions taken by authorized inspection services, the correctness of tasks performed by the Director of Transport Technical Inspection (TDT) and tasks performed by the voivodship marshal in the scope of issuing ADR certificates. The ministry competent for transport also collects information about serious accidents or failures related to the transport of dangerous goods, information on the number of ADR training companies, the number of inspections in the ADR training companies and the amount of penalties imposed on these subjects as a result of irregularities found during audit. In addition, according to competences, General Inspectorate of Road Transport and the President of the Office of Rail Transport, by the end of March of each year, provide information on the amount of imposed penalties, to the minister competent for transport. These penalties are related to the violation of regulations on the transport of dangerous goods. These institutions also provide information on the number of inspections carried out on dangerous goods transport and irregularities found in this respect - in the field of road and rail transport of dangerous goods. The same obligations as outlined above have: Head of the National Revenue Administration, Chief Commander of the Border Guard, The Police Commander in Chief. The implementation of these tasks by the minister competent for transport is aimed at monitoring incidents involving dangerous goods and actions taken in reference to these accidents. Monitoring the scale of violations of regulations concerning the transport of dangerous goods is also aimed at ensuring the best possible conditions during the road transport of dangerous goods.

According to the Act on the transport of dangerous goods, since 2012, only General Inspectorate of Road Transport has authorization to carry out inspections both on roads, 
parking lots and at the premises of entities organizing the transport of dangerous goods. The National Labour Inspectorate, Transport Technical Supervision, The State Fire Service, Inspection for Environmental Protection and National Atomic Energy Agency were deprived of the right to control at the premises of entities organizing the transport of dangerous goods.

Transport Technical Supervision participates in the process of road transport of dangerous goods, by performing its tasks in the field of keeping records of: safety advisers for the transport of dangerous goods, records of entities conducting courses for advisers, as well as the issuing the certificate of an advisor for the security of the transport of dangerous goods and ADR vehicle approval certificate.

The Act on the transport of dangerous goods specifies institutions and the scope of information that must be collected and transferred to the minister competent for transport. The authority of the Minister over entities implementing tasks in the field of transporting dangerous goods is aimed at collecting and analyzing data on dangerous goods transport operations and defining the appropriate conclusions. All the activities described above should allow to characterize overall the dangerous goods transport market, and not only in terms of irregularities and offenses.

Road accidents in transport are an unavoidable consequence of this economy branch functioning and are closely related to the situation in road traffic [10]. The scale of transport of hazardous materials is quite large, about half of all goods belongs to various types of dangerous goods i.e. materials, granulates and substances. Therefore, it is extremely important that participants in the transport of dangerous goods obey the law. According to The Road Transport Inspection, the most common causes of collisions and accidents involving dangerous goods are:

1. Transport of dangerous goods by a driver who has not completed the proper training and has not obtained the required ADR certificate.

2. Failure to obtain the required ADR vehicle approval certificate.

3. Means of transport carrying dangerous goods are not equipped with the required fire extinguishers and protective equipment specified in regulations.

4. Carrying out transport of dangerous goods in a vehicle that does not comply with technical conditions.

5. Transport of dangerous goods in packaging that does not meet the requirements of the ADR agreement.

6. Incorrect marking of the means of transport.

7. Incorrect placement and securing of loads.

8. Tiredness of drivers transporting dangerous goods.

9. Lack of proper supervision over vehicles transporting dangerous goods.

Inspectors of The Road Transport Inspection are authorized to control road transport of dangerous goods - on roads, parking lots and at the pat the premises of entities organizing the transport of dangerous goods, Police officers - on roads and parking lots, Border Guard officers - on roads and parking lots and Customs and Tax Control officers - on the territory of the Republic of Poland. 
According to the Supreme Audit Office data, 150 million tons of dangerous goods are transported annually on Polish roads, including substances that were used as chemical weapons during World Wars, and are currently used in the economy (e.g. phosgene, chlorine). Of the total number of transported dangerous goods, $72 \%$ is for liquid fuels, about $19 \%$ concern liquefied gases, and about 3\% concern toxic and corrosive substances. According to the assessment of the Supreme Audit Office, road transport of dangerous goods is carried out by at least 22 thousand suitably adapted vehicles - mainly tanks. This number of vehicles corresponds to the number of ADR vehicle approval certificates that was issued.

It is worrying that apart from monitoring the transport of sensitive materials, there is no tracking of ADR vehicles routes. It is not known by which road and at what time the transport is carried out. There is no risk analysis including this type of data. The Act of 9 March 2017 on the monitoring system for the road transport of goods (Dz. U., item 708 and 2018, item 138) introduced procedures for combating dishonest entities carrying out illegal trade in goods, without paying taxes to the state budget. Goods covered by the Act have been identified as sensitive goods. Monitoring of the sensitive goods transport is carried out via a register operating in the form of an IT system, which is managed by the Head of the National Revenue Administration and applications to the register are made via the Tax and Customs Electronic Services Portal. The transport monitoring system includes the collection and processing of data on the transport of goods, which enables monitoring of dishonest entities that trade illegally, including liquid fuels, vegetable oils, completely denatured alcohol and dried tobacco or to monitor entities that want to extort the tax. According to the amendment to the Act on the monitoring system for road and rail transport of goods (Dz. U. of 2018, item 1539), from October 1, 2018, every vehicle carrying the socalled sensitive goods must be equipped with a location system that will transfer in real time the current geolocation data of the mean of transport to the servers of the National Revenue Administration. To meet the requirement contained in the Act, transport operator throughout the entire route of transporting the goods covered by the declaration, is obliged to ensure the transmission of current geolocation data of the means of transport covered by this declaration. For this purpose, it is required to equip the means of transport with a device, which may be:

- locator, i.e. a device (e.g. tablet, smartphone) on which the software provided by the Head of the National Revenue Administration will be installed, used to monitor the route of transport of goods, or;

- $\quad$ system used by the transport operator, collecting and transmitting geolocation data of the means of transport, the so-called External Location System.

Transmitted geolocation data include: geographical coordinates regarding the location of the means of transport, its speed, date and time of obtaining these coordinates, azimuth of the means of transport, error of satellite data transmission and the number of the locator or the number of the external location system [5].

The scale of the danger associated with the transport of dangerous goods can be demonstrated by the fact that annually firefighters must eliminate the effects of events 
(leaks, collisions) with the participation of about 500 different materials, and often each substance requires a different approach, which further hinders the operations of the Fire Department. Increasingly, firefighters have to remove the consequences of road incidents involving dangerous goods, and every third such case concerns particularly hazardous substances.

There is currently no information on the transport of dangerous goods carried out by thousands of cars for which there is no obligation to meet the special requirements identified in ADR, because these transports are not subject to ADR regulations. In addition, there is no comprehensive information about vehicles transporting dangerous goods that are registered in other countries and transport these goods to Poland or as part of transit through Poland. This may represent hundreds of thousands of transports per year, by vehicles loaded with dangerous goods of all classes, which are improperly packed, transported and labeled, which pose a great danger. Lack of supervision over such transports is also particularly dangerous due to the possibility of taking over such cargo and using it for terrorist purposes, which has already occurred in Europe.

\section{Analysis of fires involving hazardous materials}

Table 2 presents the number of fires in 2015-2019, taking into account the five most common ADR factors referring to the fires in a given year.

Table 2

Number of fires in 2015-2019

\begin{tabular}{|c|c|c|c|c|c|c|}
\hline \multirow[b]{2}{*}{ Year } & \multirow[b]{2}{*}{ ADR factor } & \multicolumn{5}{|l|}{ Fires } \\
\hline & & Small & Medium & Large & $\begin{array}{l}\text { Extra } \\
\text { large }\end{array}$ & $\begin{array}{l}\text { Total } \\
\text { number }\end{array}$ \\
\hline \multirow{5}{*}{2015} & Carbon monoxide & 421 & 7 & 0 & 0 & 428 \\
\hline & $\begin{array}{l}\text { Mixtures of hydrocarbons (liquefied } \\
\text { gases) }\end{array}$ & 45 & 11 & 3 & 1 & 60 \\
\hline & Soluble Acetylene & 18 & 3 & 0 & 0 & 21 \\
\hline & Diesel fuel for diesel engines & 12 & 3 & 1 & 0 & 16 \\
\hline & Compressed natural gas & 16 & 0 & 0 & 0 & 16 \\
\hline \multirow{5}{*}{2016} & Carbon monoxide & 368 & 4 & 0 & 0 & 372 \\
\hline & $\begin{array}{l}\text { Mixtures of hydrocarbons (liquefied } \\
\text { gases) }\end{array}$ & 54 & 9 & 2 & 1 & 66 \\
\hline & Soluble Acetylene & 20 & 3 & 2 & 0 & 25 \\
\hline & Diesel fuel for diesel engines & 13 & 4 & 1 & 0 & 18 \\
\hline & Flammable liquids solution & 14 & 0 & 1 & 0 & 15 \\
\hline 2017 & Carbon monoxide & 315 & 4 & 0 & 0 & 319 \\
\hline
\end{tabular}


The analysis of organizational and legal possibilities to reduce the dangers related...

tab. 2 cont.

\begin{tabular}{|c|c|c|c|c|c|c|}
\hline & $\begin{array}{l}\text { Mixtures of hydrocarbons (liquefied } \\
\text { gases) }\end{array}$ & 69 & 6 & 0 & 0 & 75 \\
\hline & Soluble Acetylene & 12 & 5 & 2 & 0 & 19 \\
\hline & Liquefied natural gas & 18 & 1 & 0 & 0 & 19 \\
\hline & Flammable liquids solution & 18 & 1 & 0 & 0 & 19 \\
\hline \multirow{5}{*}{2018} & Carbon monoxide & 363 & 9 & 1 & 0 & 373 \\
\hline & $\begin{array}{l}\text { Mixtures of hydrocarbons (liquefied } \\
\text { gases) }\end{array}$ & 54 & 17 & 2 & 2 & 75 \\
\hline & Soluble Acetylene & 20 & 9 & 1 & 1 & 31 \\
\hline & Compressed natural gas & 18 & 1 & 0 & 0 & 19 \\
\hline & Diesel fuel for diesel engines & 13 & 2 & 1 & 1 & 17 \\
\hline \multirow{5}{*}{2019} & Carbon monoxide & 316 & 5 & 0 & 0 & 321 \\
\hline & $\begin{array}{l}\text { Mixtures of hydrocarbons (liquefied } \\
\text { gases) }\end{array}$ & 71 & 9 & 0 & 0 & 80 \\
\hline & Soluble Acetylene & 15 & 10 & 1 & 1 & 27 \\
\hline & Compressed natural gas & 13 & 5 & 0 & 0 & 18 \\
\hline & Diesel fuel for diesel engines & 13 & 1 & 0 & 1 & 15 \\
\hline
\end{tabular}

Source: Own study based on public information - Event statistics of the Decision Support System of the State Fire Service in 2015-2019 (http:/dane.gov.pl; access: 18.02.2020)

Table 3 presents the number of local threats in 2015-2019, taking into account the five most common ADR factors in a given year.

Table 3

Number of local threats in 2015-2019

\begin{tabular}{|c|c|c|c|c|c|c|c|}
\hline \multirow[b]{2}{*}{ Year } & \multirow[b]{2}{*}{ ADR factor } & \multicolumn{6}{|c|}{ Local threats } \\
\hline & & Small & Local & Medium & Large & Giant & $\begin{array}{l}\text { Total } \\
\text { number }\end{array}$ \\
\hline \multirow{5}{*}{2015} & Carbon monoxide & 174 & 3935 & 103 & 1 & 0 & 4213 \\
\hline & Flammable liquids solution & 93 & 1929 & 32 & 1 & 0 & 2055 \\
\hline & Diesel fuel for diesel engines & 44 & 1076 & 62 & 1 & 0 & 1183 \\
\hline & Compressed natural gas & 28 & 512 & 76 & 0 & 0 & 616 \\
\hline & $\begin{array}{l}\text { Mixtures of hydrocarbons } \\
\text { (liquefied gases) }\end{array}$ & 34 & 351 & 51 & 3 & 0 & 439 \\
\hline \multirow{5}{*}{2016} & Carbon monoxide & 172 & 4903 & 122 & 0 & 0 & 5197 \\
\hline & Flammable liquids solution & 73 & 1970 & 39 & 1 & 0 & 2083 \\
\hline & Diesel fuel for diesel engines & 26 & 1122 & 61 & 4 & 0 & 1213 \\
\hline & Compressed natural gas & 36 & 505 & 70 & 1 & 0 & 612 \\
\hline & $\begin{array}{l}\text { Mixtures of hydrocarbons } \\
\text { (liquefied gases) }\end{array}$ & 31 & 392 & 29 & 2 & 0 & 454 \\
\hline \multirow{2}{*}{2017} & Carbon monoxide & 179 & 5610 & 127 & 0 & 0 & 5916 \\
\hline & Flammable liquids solution & 66 & 1996 & 34 & 1 & 0 & 2097 \\
\hline
\end{tabular}


tab. 3 cont.

\begin{tabular}{|c|c|c|c|c|c|c|c|}
\hline & Diesel fuel for diesel engines & 56 & 1126 & 115 & 3 & 0 & 1300 \\
\hline & Compressed natural gas & 40 & 678 & 114 & 0 & 0 & 832 \\
\hline & $\begin{array}{l}\text { Mixtures of hydrocarbons } \\
\text { (liquefied gases) }\end{array}$ & 27 & 372 & 57 & 3 & 0 & 459 \\
\hline \multirow{5}{*}{2018} & Carbon monoxide & 142 & 5621 & 143 & 1 & 0 & 5907 \\
\hline & Flammable liquids solution & 78 & 2095 & 48 & 0 & 0 & 2221 \\
\hline & Diesel fuel for diesel engines & 56 & 1177 & 107 & 1 & 0 & 1341 \\
\hline & Compressed natural gas & 54 & 822 & 193 & 1 & 0 & 1070 \\
\hline & $\begin{array}{l}\text { Mixtures of hydrocarbons } \\
\text { (liquefied gases) }\end{array}$ & 39 & 506 & 73 & 4 & 0 & 622 \\
\hline \multirow{5}{*}{2019} & Carbon monoxide & 171 & 5475 & 147 & 1 & 0 & 5794 \\
\hline & Compressed natural gas & 84 & 1092 & 303 & 0 & 0 & 1479 \\
\hline & Flammable liquids solution & 32 & 1377 & 64 & 0 & 0 & 1473 \\
\hline & Diesel fuel for diesel engines & 71 & 1167 & 129 & 3 & 0 & 1370 \\
\hline & $\begin{array}{l}\text { Mixtures of hydrocarbons } \\
\text { (liquefied gases) }\end{array}$ & 40 & 618 & 125 & 0 & 0 & 783 \\
\hline
\end{tabular}

Source: Own study based on public information - Event statistics of the Decision Support System of the State Fire Service in 2015-2019 (http:/dane.gov.pl; access: 18.02.2020)

\section{Analysis of the possibilities of improving the safety of ADR transport}

Transport of dangerous goods requires specialized knowledge of the composition, chemical and physical properties, as well as knowledge of specialized packaging and means of transport. Due to the scale of dangerous goods transported, the transport industry and regulations related to transport services are of elementary importance. Both international law and national law contain legal norms specifying the manner of providing the abovementioned services. Since the entry of the Act on the transport of dangerous goods, minister competent for transport is the authority supervising the transport of dangerous goods by road. It seems expedient to introduce such solutions that will minimize the dangers arising from the transport of dangerous goods. There is an urgent need to absolute use the provisions of the Act on the transport of this type of goods, first in the scope of supervising the road transport of dangerous goods and to carry out controls on the performance of this activity by entities obliged by law, as well as in the scope of realizing the transport process of dangerous goods. To improve the current situation, according to the Report of the Supreme Audit Office, the following actions should be taken:

- carry out an assessment of the functioning of units subordinated to or supervised by the ministry,

- collect and analyze information provided by the authorities and units indicated in the Act on the transport of dangerous goods, 
- in case of disclosure of irregularities related to the transport of dangerous goods, appropriate corrective action should be taken and, if necessary, appropriate procedures should be implemented,

- ongoing monitoring of events involving dangerous goods, which will allow to determine the scale and type of violations,

- supervise the activities of the Director of Transport Technical Inspection in the scope of keeping a register of advisors for the security of the transport of dangerous goods or issuing an advisor certificate and vehicle approval certificate for the transport of dangerous goods,

- oversee the implementation of tasks performed by voivodeship Marshals, including in the scope of issuing certificates on successful completion of relevant courses for drivers transporting dangerous goods.

Limiting the dangers related to transport and the effects of breakdowns should be preceded by an analysis of data in this regard. Safety in the road transport of dangerous goods may be improved by currently used modern solutions that allow the transmission of information via advanced wireless techniques. Collecting telematics data in real-time can also increase road transport safety, because this system allows to transfer current information to parties involved in transport of potential dangerous goods [6, 7]. Monitoring the location of the vehicle will make it possible to determine the main routes of vehicles carrying hazardous materials. This will enable risk assessment within the transport network. On this basis, it will be possible to optimize routes due to the emerging threats associated with driving through points significant for reasons of safety:

- public safety (blocking of major transport hubs may lead to paralysis of major transport routes),

- biological safety (contamination of areas important for human communities, e.g. watercourses used to supply large cities with water, deliberate unsealing of chlorine tanks etc.),

- danger of explosion (transport of pyrotechnics, explosives, etc.),

- threats of terrorist attack, e.g. by driving a vehicle into a crowd.

\section{Summary}

Dangerous materials are not monitored in a similar way to sensitive goods. It is estimated that their share in the total volume of transported goods may reach even $50 \%$. It seems reasonable to implement a monitoring and surveillance system in view of the growing threat of small and large scale terrorist attacks.

Implementing the monitoring system would require extending the current obligation to monitor sensitive goods and include to this system monitoring of dangerous goods. Organizational and technical solutions are ready, so it would only be necessary to change the applicable national laws in this respect. Furthermore, the costs of implementing this type of system would not significantly burden transport companies, because currently most of them use vehicle fleet monitoring systems or the so-called smart tachographs. These 
enterprises could also use the available data about their own vehicles for analysis for the needs of the company in order to improve vehicle safety and optimize routes, and thus reduce costs in the company.

The article has been presented on 13th International BRD GAMBIT 2020 Conference. Article was co-funded by the Science Excellence programme of the Ministry of Science and Higher Education.

\section{References}

1. Bęczkowska S.: The method of optimal route selection in road transport of dangerous goods, Transportation Research Procedia, Volume 40, 2019.

2. Conca A., Ridella Ch., Sapori E.: A Risk Assessment for Road Transportation of Dangerous Goods: A Routing Solution, Transportation Research Procedia, Vol. 14, 2016.

3. Cordeiro F.G., Bezerra B.S., Palcheco Peixoto A.S., Ramos R.A.R.: Methodological aspects for modeling the environmental risk of transporting hazardous materials by road, Transportation Research Part D: Transport and Environment, Vol. 44, May 2016.

4. Grzegorczyk K., Buchcar R.: Carriage of dangerous goods by road ADR 2017-2019, Wydawnictwo ADeR BUCH-CAR, Błonie 2016.

5. Laarabia M.H., Boulmakoul A., Sacile R., Garbolino E.: A scalable communication middleware for real-time data collection of dangerous goods vehicle activities, Transportation Research Part C: Emerging Technologies, Vol. 48, 2014.

6. Łukasik Z., Kuśmińska-Fijałkowska A., Kozyra J.: Transport of dangerous goods by road from a European aspect. Zeszyty Naukowe. Transport / Politechnika Śląska, z. 95, 2017.

7. Purdy G.: Risk analysis of the transportation of dangerous goods by road and rail, Journal of Hazardous Materials, Vol. 33, Iss. 2, 1993.

8. Reniers G.L.L., Dullaert W.: A method to assess multi-modal Hazmat transport security vulnerabilities: Hazmat transport SVA, Transport Policy, Vol. 28, July 2013.

9. Różycki M.: Vademecum 1 dangerous goods practice, Handbook 2019-2021, Wydawnictwo Emepress sp. z o.o., Mikołów 2015.

10. Wen-Kai K.H., Show-Hui S.H., Wen-Jui T.: Evaluating the risk of operational safety for dangerous goods in airfreights - A revised risk matrix based on fuzzy AHP, Transportation Research Part D: Transport and Environment, Vol. 48, 2016. 